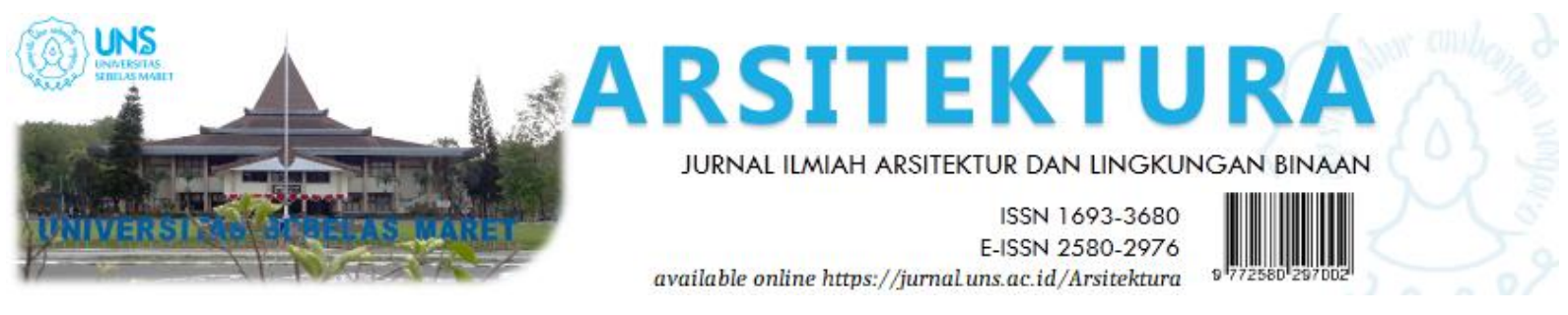

Volume 19 Issue 1 April 2021, pages:117-126

\title{
Karakteristik Penggunaan Ruang dan Strategi Spasial Home- Based Enterprise dalam konteks Informalitas
}

\section{Characteristics of spatial use and spatial strategies of Home-Based Enterprise in the context of informality}

\author{
Pascal Rivandi $^{{ }^{*}}$, Murtanti Jani Rahayu ${ }^{2}$ \\ Department Urban and Regional Planning, Faculty of Engineering Universitas Sebelas Maret ${ }^{l}$ \\ pascalrivandi22@student.uns.ac.id* \\ Regional Development Information Center, Institute of Research and Community Services, Universitas \\ Sebelas Maret, Surakarta, Indonesia ${ }^{2}$
}

DOI: https://doi.org/10.20961/arst.v19i1.46863

Received: December 22,2020 Revised: January 12,2021 Accepted: February 3,2021 Available online: April 30,2021

\begin{abstract}
Home-Based Enterprise as one type of informalityin urban area with home as the ma in resource. This paper analyses home-based enterprises focusing on identifying characteristics of spatial use in Home-Based Enterprise which is divided into threetype of bussiness, production, serviceand sales. The characteristics spatial use of the three types of Home-Based Enterprise, are very different and will determine spatial strategies in HBE development. Spatial strategy is a step to develop HomeBased Enterprise, through an adaptivestrategy consisting of adaptation strate gy by sharing, adaptation strategy by extending andadaptation strate gy by shifting. The case study method conducted in making this paper is qualitative by describing characteristics of spatial use concerning on the home-based enterprises and spatial strategies based on the three types of Home-Based Enterprise. It is concluded that there is a relationship between the characteristics of spatial use and spatial strategies in the development of Home-Based Enterprise.
\end{abstract}

Keywords: Home-Based Enterprise, Characteristics, Strategy, Informality

\section{PENDAHULUAN}

Lahirnya sektor informal tidak terlepas dari beragam pendapat dan dasar keterkaitan lintas sektoral. Kehadiran sektor informal disikapi beragam pihak, ada yang menganggap sektor informal sebagai penyebab kerugian sosial, masalah kebersihan, kesehatan hingga keindahan kota (Payaman, 1985 Cross\&Karides, 2007). Namun disisi lain sektor informal merupakan jaring pengaman tenaga kerja yang mampu memberikan lapangan kerja (Payaman, 1985). Dampak positif dan negatif kehadiran sektor informal, menjadi bekal untuk memahami bagaimana lahirnya sektor informal. Menurut Mulyadi (2003: 95) sektor informal adalah unit-unit usaha yang tidak atau sama sekali menerima proteksi ekonomi secara resmi dari pemerintah, dimana kebijakan pemerintah untuk membantu golongan ekonomi lemah kadang tidak sampai sektor ini. Pendapat tersebut merujuk pada definisi bahwa sektor informal merupakan sektor yang "diluar" 
kepentingan pemerintah, dan luput dari pandangan pemerintah (Mead \& Morrisson, 1996; Manning, 2001; Cross\&Karides, 2007; Rahayu dkk, 2020). Secara garis besar definisi dari sektor informal merujuk pada tidak adanya keterkaitan antara pemerintah dengan sektor informal. Di sisi lain sektor informal juga mengisi ruang-ruang di perkotaan yang merupakan teritori pemerintah.

Di Indonesia, sektor informal muncul berhubungan dengan besarnya populasi dan pertumbuhan angkatan kerja yang tidak seimbang dengan pertumbuhan perekonomian dan ketersediaan lapangan kerja dalam suatu wilayah (Hidayat, 1998; Rahmatia, 2004). Kelahiran sektor informal tidak dipungkiri berkaitan dengan masalah ketenagakerjaan. Pertumbuhan penduduk menjadi dasar penting dimana memicu supply tenaga kerja yang terus bertumbuh, di sisi lain demand dari tenaga kerja atau dalam hal ini lapangan kerja masih terbatas. Adanya celah antara permintaan dan ketersediaan menjadi awal kemunculan sektor informal. Setiono (2004:5) menyebutkan bahwa sektor ini telah memberikan andil \pm $65 \%$ dalam penyerapan tenaga kerja. Sektor informal menjawab bagaiamana solusi atas celah ketenagakerjaan dan lemahnya pemerintah, dengan mengakomodasi tenaga kerja.

Informalitas dalam praktek perkotaan menjadi nyata ketika sistem masyarakat dipelajari dalam sudut informalitas. Masalah perkotaan yang semakin dinamis membutuhkan model penyelesaian yang semakin beragam. Peran kota dalam agenda hijau sangat diakui dimana dengan urbanisasi yang semakin masif. Informal perkotaan dari segi ekonomi merupakan sektor yang mampu menampung tenaga kerja yang cukup besar. Semakin pentingnya perekonomian informal, terutama dalam kondisi kemiskinan, menambah tantangan dalam mengembangkan pendekatan baru untuk perlindungan dan perbaikan lingkungan, terutama jika hal ini akan mendukung transisi ke ekonomi yang lebih inklusif serta lebih hijau dan tahan iklim (Brown, 2014).

Usaha kecil menjadi salah satu cara untuk masyarakat meningkatkan kondisi ekonomi. Pengembangan usaha dapat dimulai dari ruang yang paling mudah, yaitu dari rumah. Dari rumah usaha dapat berkembang secara bertahap dengan modal awal yang kecil dan pasar yang kecil menjadikan usaha kecil berbasis rumah menjadi peluang masyarakat dalam meningkatkan ekonomi. Usaha rumahan juga merupakan salah satu cara untuk mewujudkan perekonomian dan perumahan yang berkelanjutan bagi penghuninya. Konsep usaha berbasis rumah mampu menghasilkan pendapatan tanpa mengeluarkan biaya perjalanan kerja maupun biaya tambahan karena memanfaatkan rumah sebagai tempat kegiatan ekonomi. Tipologi Usaha berbasis Rumahan dapat dibagi dalam dua jenis, pertama penjualan untuk menjual barang atau jasa, sedangkan kedua adalah industri kecil untuk memproduksi atau menyelesaikan produk (Tyas, 2009).

Kegiatan ekonomi di lingkungan hunian akan membutuhkan beragam upaya dari pelaku mulai dari menampung pekerjaan ke dalam rumah, mengganti bentuk rumah agar bisa menampung pekerjaan hingga merenovasi hunian. Turner (1976) mengungkapkan bahwa ada dua upaya yang perlu dilakukan penghuni terhadap rumahnya untuk menjadi HBE, yaitu penyesuaian hunian dan adaptasi hunian. Kegiatan yang menggunakan ruang hunian maupun halaman, untuk suatu kegiatan usaha dapat membentuk pola lingkungan kerja, sosial, peningkatan ekonomi. Kegiatan tersebut menimbulkan terjadinya perubahan ruang, pergeseran teritori dan nilai privasi penghuni. (Istiqomah, Dewi, dan Fajria, 2011).

Kegiatan usaha rumah tangga / Home Base Enterprise (HBE) yang bertumpu pada rumah tangga menjadi salah satu penyebab dari adanya proses transformasi Hunian (Soegiono, Setijanti, \& Faqih, 2010). HBE mewadahi aktivitas usaha dan aktivitas rumah tangga. Penggunaan ruang pada HBE memiliki proporsi yang berbeda-beda (Fitriyani,2015). Pertama tipe campuran merupakan tipe yang didominasi oleh fungsi hunian. Belum terdapat batasan antara aktivitas hunian dan aktivitas usaha. Kedua, tipe berimbang dimana mulai mempertegas batasan yang jelas antara fungsi hunian dan usaha. Ketiga merupakan tipe terpisah dimana fungsi usaha mendominasidan sudah terpisan antara aktivitas usaha dan aktivitas hunian. 
Karakteristik penggunaan ruang dalam HBE akan memiliki implikasi dalam strategi perkembangan HBE. Menurut (Santos, 1977; Soetomo,1988; Rahayu, 2020) menyebutkan terdapat dua perubahan perkembangan pada sektor infromal di perkotaan yaitu evolusi dan involusi. Evolusi berarti proses peningkatan kondisi secara materi dari kegiatan sektor informal, dan memungkinkan untuk beralih ke sektor formal, sedangkan involusi adalah proses keadaan tetap miskin meski bertambah banyak namun dalam kondisi tetap lemah. Dalam penelitian Marsoyo (2012), dimana dibahas mengenai strategi adaptasi rumah yang digunakan dalam usaha berbasis rumah menghasilkan tiga strategi yaitu, sharing atau ruang domestik dalam rumah yang semula sebagai kegiatan domestik juga dibagikan untuk kegiatan ekonomi, extending atau memperluas rumah dalam bentuk ruang tambahan untuk kegiatan ekonomi, dan shifting atau memanfaatkan ruang yang digunakan untuk dua kegiatan domestik dan ekonomi yang dibedakan oleh waktu.

Karakterisitk penggunaan ruang HBE sebagai salah satu bentuk ekonomi informal berkaitan dengan tingkat kesejahteraan penghuni rumah yang kemudian akan menggambarkan seberapa alokasi ruang untuk usaha Alokasi ruang usaha yang disiapkan kemudian akan menentukan strategi spasial dalam pengembangan HBE. Penelitian Marsoyo (2012) menghasilkan tiga strategi spasial dari HBE di Kota Yogyakarta. Dengan demikian, karakteristik penggunaan ruang dalam HBE memiliki pengaruh dalam strategi spasial pengembangannya Tujuan penelitian adalah untuk mengkaji karakteristik penggunaan ruang HBE dan melihat strategi spasial dalam pengembangannya dalam konteks informalitas kota.

\section{METODE}

Metode yang digunakan dalam penelitian ini adalah metode penelitian diskriptif kualitatif. Pendekatan kualitatif dipilih untuk mengeksplorasi dan memahami makna dimana bersumber dari tindakan atau ungkapan (Moleong, 2006). Penelitian kualitatif berupaya mengungkap kondisi alamiah di lapangan. Pelaku HBE dengan beragam latar belakang akan ditemukenali bagaiamana karakteristik pemanfaatan ruang dalam usaha berbasis rumah serta strategi pengembangan yang digunakan. Data kualitattif didapatkan dari hasil observasi dan wawancara terhadap pelaku HBE di permukiman Kota Surakarta.

Pengumpulan data menggunakan metode pengumpulan data primer dan sekunder. Metode pengumpulan data primer bertujuan untuk mengetahui penggunaan ruang $\mathrm{HBE}$ melalui wawancara dan observasi lapangan. Wawancara dilakukan ke masyarakat dalam hal ini pelaku HBE di kawasan permukiman Kota Surakarta. Narasumber wawancara dipilih berdasarkan teknik purposive sampling dimana merupakan teknik pengambilan sampel sumber data dengan pertimbangan tertentu (Sugiyono 2016:85). Teknik purposive sampling berfokus pada kriteria pelaku HBE dengan jenis usaha yaitu usaha produksi, usaha jasa dan usaha penjualan.

Observasi lapangan bertujuan untuk memperoleh gambaran dalam penggunaan ruang dan aktivitas penghuni dalam usaha berbasis rumah. Data yang dibutuhkan berupa aktivitas usaha berbasis rumah, gambaran alokasi ruang yang kemudian dianalisis untuk menghasilkan sketsa penggunaan ruang HBE dan strategi spasial yang dipilih.

Dalam metode pengumpulan data sekunder dilakukan dengan kajian teori dan literatur melalui telaah terhadap hasil penelitian sebelumnya yang berkaitan. Teori penggunaan ruang dalam usaha berbasis rumah dan strategi adaptasi hunian dalam pengembangan HBE menjadi dasar untuk melihat karakteristik penggunaan ruang dan strategi spasial pengembangan HBE. Data yang didapatkan kemudian diinterpretasi dan dianalisis sebagai upaya mengungkap karakteristik penggunaan ruang $\mathrm{HBE}$ dan keterkaitan dengan strategi spasial dalam pengembangan $\mathrm{HBE}$. 
Identifikasi jenis usaha berbasis rumah

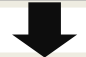

Identifikasi ka rakteristik usaha berbasis rumah

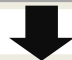

Ana lisis penggunaan ruang dalam HBE

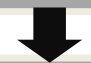

Analisis Stra tegi Spasial Usaha Berbasis Rumah

Gambar 1. AlurPenelitian

\section{HASIL DAN PEMBAHASAN}

Home Based Enterprise memadukan dua kegiatan dalam rumah dimana terdiri kegiatan hunian dan kegiatan ekonomi. Hunian dan usaha berada dalam satu teritori dapat dikateogrikan dalam tiga jenis yaitu usaha produksi, jasa, maupun perdagangan.

\subsection{Identifikasi Jenis Usaha berbasis Rumah}

Usaha berbasis rumah mempunyai atribut usaha untuk menjelaskan jenis usaha yang dimiliki. Jenis usaha yang dimiliki dapat diidentifikasi mempunyai keterkaitan dengan jenis pekerjaan sebelum pelaku membuka usaha berbasis rumah. Pengalaman kerja yang dimiliki selain menjadikan pengalaman dan ketrampilan juga menghasilkan relasi dengan pihak-pihak pendukung kegiatan usaha. Relasi kemudian akan membantu dalam menjaga keberlanjutan usaha dalam hal ini seperti relasi bahan baku, pasar konsumen dan penyedia alat atau properti pendukung usaha. Relasi dalam usaha berbasis rumah juga menciptakan iklim usaha yang kondusif yaitu melalui pertukaran informasi usaha Pada HBE di lingkungan permukiman terdapat jenis usaha produksi, jasa dan perdagangan.

\subsection{Identifikasi Karakteristik Usaha berbasis Rumah}

Karakteristik usaha berbasis rumah mempunyai keberagaman yang bergantung pada jenis usaha yang dilakukan.

\section{a. Usaha Produksi}

Jenis usaha produksi makanan memiliki kebutuhan ruang yang fleksibel dimana merujuk pada produksi makanan yang berkaitan dengan dapur dapat menjadi satu kesatuan dengan dapur dalam hunian. Usaha produksi makanan mempunyai kebutuhan alat dan properti yang sudah tersedia dalam hunian, sehingga untuk memulai HBE tidak banyak membutuhkan properti pendukung tambahan.Hal tersebut juga berpengaruh terhadap modal usaha awal yang dibutuhkan pelaku HBE. Produksi makanan di lain sisi dalam upaya penjualan produk juga dapat memanfaatkan ruang yang sudah tersedia, mengingat produksi makanan dalam skala rumahan cenderung mempunyai pasar yang kecil.

\section{b. Usaha Jasa}

Berbeda dengan jenis usaha produksi makanan, usaha jasa membutuhkan ruang khusus untuk ketersediaan alat dan properti pendukung. Usaha jasa tidak terlepas dari ketersediaan properti khusus untuk menunjang kegiatan usaha yang dilakukan. Dalam hal ini ketersediaan alat dan properti juga bergantung pada spesifik jenis jasa, usaha jasa cenderung mempunyai cakupan skala yang lebih luas daripada usaha produksi makanan. Mengingat usaha jasa tidak terbatas pada skala lokal, namun lebih mengutamakan spesfikasi dari pelaku usaha jasa. Modal dalam usaha jasa juga cenderung lebih besar daripada produksi makanan, berkaitan dengan alat dan properti yang mendukung kegiatan usaha.

\section{c. Usaha Penjualan}

Usaha penjualan atau perdagangan barang kebutuhan konsumsi merupakan jenis usaha berbasis rumah yang paling banyak ditemui. Usaha penjualan barang merupakan jenis usaha dengan kebutuhan alat dan properti yang relatif tidak banyak. Pelaku usaha penjualan juga mempunyai skala pasar yang lebih luas yang bergantung pada lokasi usaha. Lokasi usaha yang strategis dalam hal ini seperti berdekatan dengan jalan umum atau berdekatan dengan pusat perdagangan dan jasa akan berdampak pada jumlah dan variasi pelanggan. Modal dalam usaha penjualan barang tergolong tinggi bergantung dari kelengkapan produk yang dijual dan daya tampung penjualan. 


\subsection{Analisis Penggunaan ruang HBE}

Alokasi penggunaan ruang selain merujuk pada jenis usaha, juga berkaitan dengan skala pelayanan serta pasar yang diincar. Jenis usaha akan memberikan pengaruh pada seberapa luas alokasi ruangan, dimana masing-masing jenis usaha mempunyai alat atau properti yang berbeda sesuai kebutuhan.

\section{a. Usaha Produksi}

Jenis usaha produksi makanan dengan karakteristik penggunaan ruang multi use dimana dalam produksi makanan, ruangan dapur menjadi ruang utama untuk produksi. Dapur dalam usaha produksi berbasis rumah berperan ganda sebagai pendukung kegiatna hunian dan pendukung kegiatan ekonomi. Selain ruangan dapur sebagai ruang produksi, teras juga berperan ganda baik sebagai hunian dan juga ruang pemasaran produk untuk kegiatan usaha. Berikut merupakan sketsa penggunaan ruang hasil analisis dari gambaran penggunaan ruang dari narasumber usaha produksi berbasis rumah di permukiman Kota Surakarta.

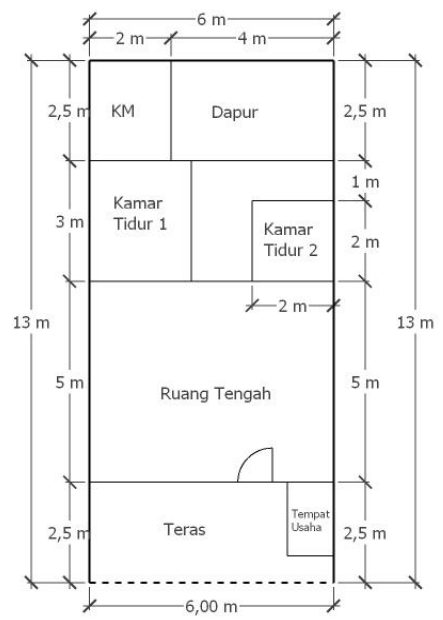

Gambar 2. Penggunaan ruang HBE dalam jen is usa ha produksi

Penggunaan ruang dalam usaha produksi makanan memiliki karakteristik campuran. Karakteristik penggunaan ruang terpisah dicirikan dengan belum jelas batasan antara ruang hunian dan ruang usaha. Karakteristik campuran juga menekankan pada dominasi ruang hunian masih mendominasi daripada ruang usaha. Berikut merupakan salah satu usaha produksi berbasis rumah di permukiman Kota Surakarta

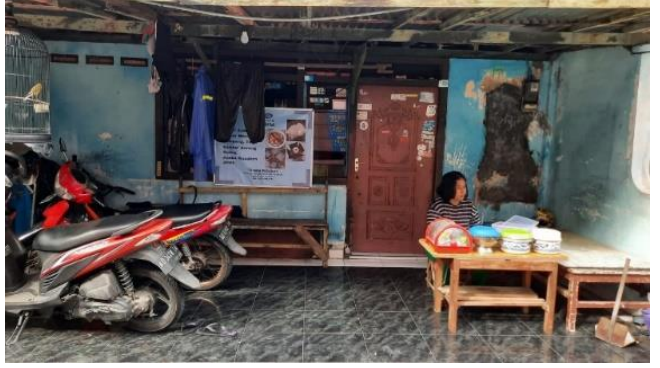

Gambar 3. HBE jenis usaha produksi

Dalam karakteristik penggunaan ruang campuran dapat diidentifikasi dengan belum adanya batasan antara ruang hunian dan ruang usaha. Kegiatan usaha dan hunian dapat berdampingan dalam ruangan yang sama. Hal tersebut berdampak pada tingkat privasi kegiatan hunian yang cenderung kurang terjaga. Dapur dan teras menjadi ruangan yang berperan multi use dalam usaha berbasis rumah produksi makanan, yang kemudian akan berpengaruh lebih dalam perilaku pemilik hunian.

\section{b. Usaha Jasa}

Jenis usaha berbasis rumah dalam usaha jasa mempunyai karakteristik penggunaan ruang berimbang. Penggunaan ruang berimbang merujuk pada alat dan properti jasa yang membutuhkan ruangan khusus dengan luasan yang bergantung pada jenis jasa. Ruang terpisah akan memudahkan dalam pengelolaan dan perawatan alat dan properti pendukung usaha. Berikut merupakan sketa penggunaan ruang hasil analisis dari gambaran penggunaan ruang dari narasumber usaha jasa berbasis rumah di permukiman Kota Surakarta.

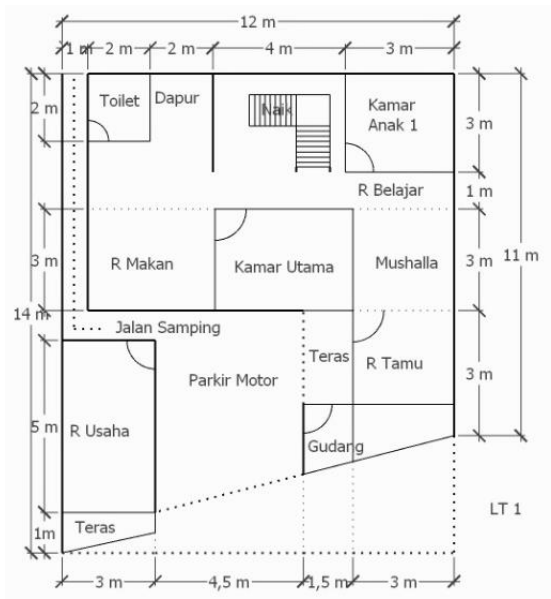

Gambar 4. Penggunaan ruang HBE dalam jenis usaha jasa Lantai 1 


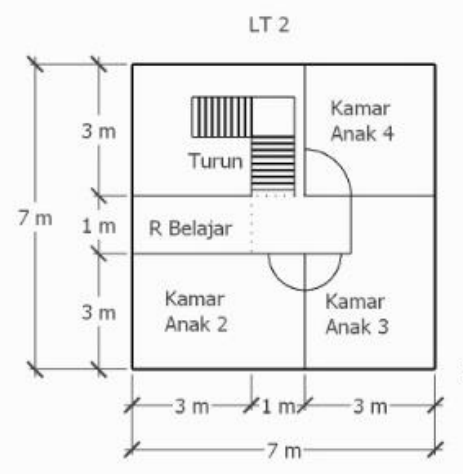

Gambar 5. Penggunaan ruang HBE dalam jenis usaha jasa Lantai 2

Karakteristik penggunaan ruang berimbang mmempunyai batasan yang sudah mulai jelas antara kegiatan usaha dan hunian. Adanya batasan antara kegiatan hunian dan usaha namun belum memisahkan secara utuh antara fungsi hunian dan usaha. Masih dapat diidentifikasi keterkaitan antar ruang dalam satu bangunan hunian yang utuh. Tingkat privasi kegiatan hunian masih cenderung kurang terjaga dalam karakteristik terpisah, berkaitan dengan masih adanya keterkaitan antar ruang hunian dan ruang usaha. Keberadaan pembatas antar ruang juga berpengaruh dalam perilaku pemilik hunian yang merasa nyaman. Berikut merupakan salah satu usaha jasa berbasis rumah di permukiman Kota Surakarta.

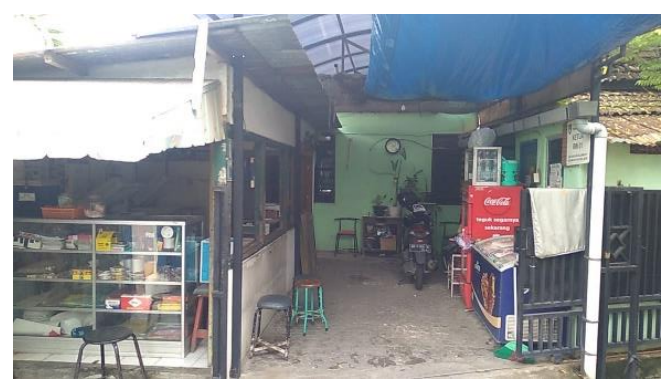

Gambar 6. HBE jenis usaha jasa

Keterkaitan antara kegiatan hunian dan usaha dapat juga diidentifikasi dengan adanya overlapping space kegiatan usaha yang kemudian bercampur dengan ruang hunian, walaupun secara umum sudah adanya batasan antar ruang. Alokasi penggunaan ruang usaha dengan hunian secara umum sangat dipengaruhi luasan total dari hunian. Dominasi usaha tidak secara eksplisit nampak karena berkaitan dengan luasan hunian, namun di lain sisi kegiatan usaha secara eksplisit dapat teidentifikasi secara langsung melalui batasan antar ruang hunian dan usaha.

\section{c. Usaha Penjualan}

Jenis usaha berbasis rumah penjualan barang konsumsi mempunyai karakteristik terpisah. Karakteristik terpisah tidak secara eksplisit menunjukan bahwa adanya pemisahan secara fisik bangunan. Ruang usaha tetap dalam satu kesatuan bangunan dengan ruang hunian, namun batasan yang ada memberikan kesan pemisahan antar ruang. Berikut merupakan sketa penggunaan ruang hasil analisis dari gambaran penggunaan ruang dari narasumber usaha penjualan berbasis rumah di permukiman Kota Surakarta.
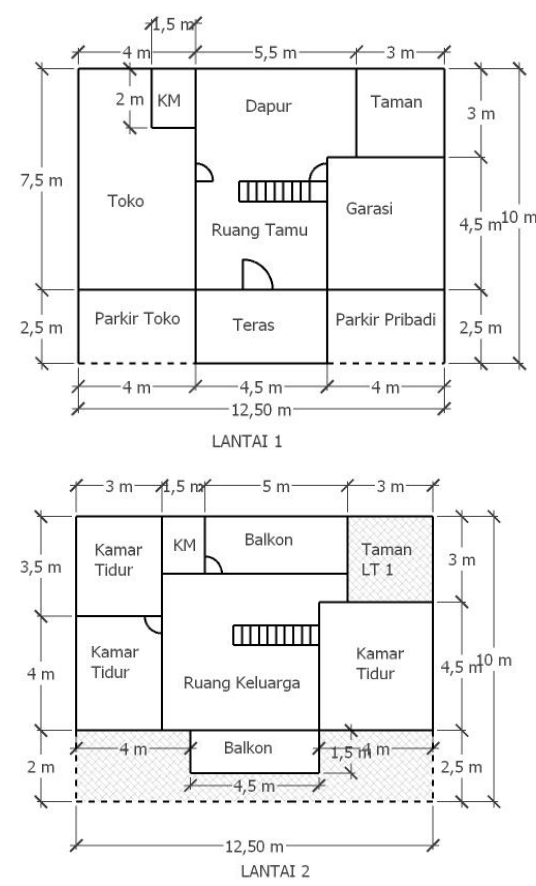

Gambar 7. Penggunaan ruang HBE dalam jen is usaha penjualan lantai 1 dan 2

Dalam karakteristik terpisah, kegiatan usaha dapat teridentifikasi secara langsung dengan batasan yang kuat dengan kegiatan hunian. Kegiatan terpisah dalam usaha penjualan barang dipilih mengingat pada kebutuhan ruang untuk produk / barang yang ditawarkan. Kuantitas produk sangat bergantung pada besaran daya tampung dari kegiatan usaha. Dalam karakteristik terpisah, tingkat privasi dari kegiatan hunian dapat lebih terjaga.dan perilaku pemilik hunian dapat lebih leluasa dan merasa nyaman. Berikut merupakan salah 
satu usaha penjualan berbasis rumah di permukiman Kota Surakarta.

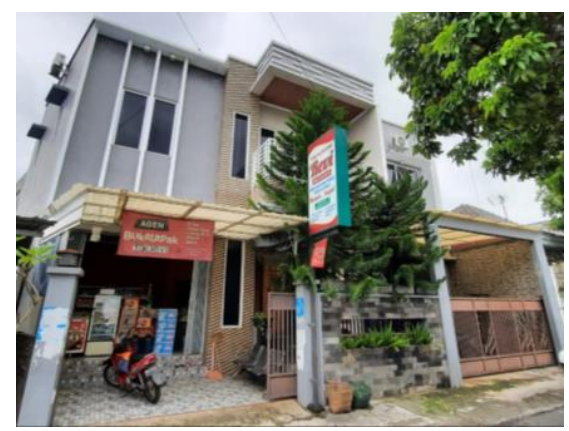

Gambar 8. HBE jenis usaha penjualan

Karakteristik terpisah menjadikan kegiatan usaha mudah diidentifikasi dan dapat menggambarkan dominasi kegiatan usaha daripada kegiatan hunian, walaupun secara alokasi penggunaan ruang sangat bergantung pada luasan lahan total hunian. Pembatasan ruang lebih nampak sehingga meniadakn keterkaitan antar kegiatan hunian dan kegiatan usaha sangat kecil. Karakteristik terpisah juga menegaskan teritori kegiatan usaha lebih kuat dan menghindai adanya overlapping space dari kegiatan usaha yang mengganggu kegiatan hunian.

\subsection{Analisis Strategi Spasial HBE}

Perkembangan sektor informal perkotaan untuk mengarah menuju evolusi atau involusi mulai dapat teridentifikasi berdasarkan karakteristik penggunaan ruang yang kemudian akan membentuk strategi spasial. HBE untuk dapat menuju evolusi membutuhkan pencapaian yang tinggi dan tidak mudah. Di sisi lain involusi perlu dihindari dan menjaga keberlanjutan sektor informal dalam hal ini HBE dapat ditempuh dengan strategi spasial berupa penyesuaian atau adaptasi ruang. Strategi penyesuaian ruang merupakan langkah pengembangan HBE dengan tidak menggunakan ruang publik. Strategi adaptif yang dilakukan rumah tangga terkait dengan usaha berbasis rumah diungkap dalam penelitian (Marsoyo, 2012). Tiga strategi utama berupa sharing, extending dan shifting yang didasarkan pada kesamaan antar karakteristik yang berimplikasi pada ruang.

\section{a. Usaha Produksi}

Hasil observasi dalam penelitian ini mengungkap jenis usaha produksi makanan menerapkan adaptasi ruang dengan tipe shifting dalam upaya menjaga keberlanjutan usaha produksi makanan dan menghindari terjadinya involusi. Strategi shifting meminimalisir modal yang harus dikeluarkan untuk penyediaan ruang usaha tambahan. Ruang usaha dapat berlangsung bergantian dengan ruang hunian dalam hal ini ruang dapur sebagai produksi dan ruang teras sebagai ruang pemasaran. Pada ruang dapur dapat dimanfaatkan bergantian untuk kegiatan memasak sebagai bagian dari usaha dan memasak sebagai bagian dari kegiatan hunian. Untuk ruang teras dimana penjualan atau pemasaran produk makanan dimulai pada jam tertentu yang juga dapat bergantian dengan kegiatan hunian yang dilakukan pada ruang teras, Penggunaan ruang dengan strategi shifting dibedakan oleh waktu dalam kegiatan usaha dan kegiatan hunian. Strategi shifting diterapkan pada HBE skala kecil dan merintis dimana sedang mengupayakan untuk menjauh dari kemungkinan involusi. Juga strategi ini dipilih merupakan hasil dari kondisi modal dalam pengembangan HBE yang berusaha meminimalisir modal usaha dalam kerangka penyediaan ruang usaha.

\section{b. Usaha Jasa}

Jenis usaha jasa cenderung sudah mempunyai ruang usaha yang dipisahkan dari ruang hunian namun masih terdapat keterkaitan dengan kegiatan hunian. Strategi sharing diterapkan berkaitan dengan upaya menciptakan ruang usaha tambahan. Dimana dengan memodifikasi ruang hunian yang tidak dimanfaatkan dengan optimal yang kemudian menjadi ruang usaha yang masih termasuk dalam aset fisik pelaku HBE. Dalam jenis usaha jasa yang diidentifikasi, ruang usaha yang digunakan dalam usaha jasa merupakan modifikasi dari ruang gudang yang merupakan bagian dari kegiatan hunian. Modifikasi kemudian dapat menciptakan ruang baru untuk kegiatan usaha. Dengan latar belakang sebelumnya merupakan ruang gudang dan bagian tidak terlepas dari kesatuan hunian, maka keterkaitan yang ada dengan ruang lain di hunian sangat kuat. Langkah yang diambil kemudian dengan memberikan pembatasan 
dan penanda ruang untuk kegiatan usaha, walaupun keterkaitan dengan ruang-ruang lain dalam hunian masih tergolong kuat.

Strategi sharing ruang juga berimplikasi terhadap kegiatan hunian karena masih adanya keterkaitan antara ruang hunian dan ruang usaha. Belum dapat seutuhnya menciptakan batasan antara kegiatan usaha dan kegiatan hunian. Untuk memperkuat identitas ruang usaha, kemudian digunakan cara pembatasan serta penandaan ruang. Strategi sharing memiliki daya tahan lebih daripada shifting, yang merujuk pada kemampuan untuk merubah fungsi ruang dan kemungkinan pertumbuhan usaha yang lebih tinggi. Sharing berupaya dengan tetap memiliki atribut usaha yang lebih jelas daripada strategi shifting, berupa ruang yang lebih nyata walaupun dengan batasan yang tidak terlalu kuat.

\section{c. Usaha Penjualan}

Usaha penjualan secara spesifik mempunyai pembatasan yang kuat antara ruang usaha dan ruang hunian. Strategi extending menjadi diterapkan dengan membuat ruang tambahan untuk kegiatan utama bisnis, ruang tersebut dibangun dalam satu kesatuan dengan bangunan hunian dan masih merupakan aset fisik pelaku HBE. Extending dalam strategi spasial penyesuaian ruang tidak mengarah pada perluasan ruang yang bukan hak milik atau dalam hal ini ruang-ruang publik.

Jenis usaha penjualan memilih strategi extending dengan membangun bagian depan rumah untuk kegiatan usaha secara khusus. Pembangunan dilakukan secara terencana untuk memulai kegiatan usaha. Extending berupaya menjadikan kegiatan usaha untuk lebih dapat diidentifikasi dengan lebih baik oleh konsumen. Strategi extending merupakan strategi dengan modal usaha yang terbesar, modal diperlukan dalam penyediaan ruang usaha dengan batasan yang kuat dengan ruang hunian. Dengan pemisahan ruang usaha dan hunian secara nyata, peluang evolusi untuk HBE semakin lebih kuat. Secara nyata strategi extending sudah berusaha meniadakan kemungkinan involusi dengan menegaskan kegiatan usaha yang lebih kuat dimana juga berpengarruh terhadap daya tampung usaha yang lebiih besar.

\section{KESIMPULAN}

Home Based Enterprise mempunyai karakteristik penggunaan ruang untuk hunian dan usaha, dimana karakteristik penggunaan ruang dibentuk dari jenis usaha. Setiap jenis usaha akan mempunyai alat dan properti usaha, dominasi kegiatan, skala pelayanan dan lokasi ideal yang beragam. Jenis usaha berbasis rumah dikelompokkan dalam tiga jenis yaitu usaha produksi, usaha jasa, dan usaha penjualan/perdagangan.

Perkembangan HBE dalam konteks informalitas secara umum terdiri dari evolusi maupun inovolusi. Karakterisitk penggunaan ruang HBE kemudian akan menentukan strategi spasial pengembangannya dan hasil akhirnya menunjukan perkembangan evolusi atau involusi. Strategi spasial HBE dapat ditempuh dengan upaya penyesuaian ruang atau adaptasi ruang. Strategi adaptasi ruang ruang dalam tiga strategi yaitu sharing, extending dan shifting.

Jenis usaha merupakan dasar utama dalam mengidentifikasi karakteristik penggunaan ruang dalam usaha berbasis rumah. Tiga jenis usaha yang teridentifikasi juga mempunya tiga karakterisitik penggunaan ruang yang berbeda satu dengan yang lain. Kunci dalam karakteristik penggunaan ruang dalam HBE adalah seberapa kuat batasan yang dibentuk dalam menghadirkan kegiatan usaha di lingkungan hunian.

Strategi spasial dalam hal untuk penyesuaian atau adaptasi ruang menjadi kunci dalam pengembangan HBE yang menitikberatkan hunian sebagai sumber daya utama kegiatan usaha. Strategi spasial yang tepat akan menjadikan usaha berbasis rumah menjadi berkembang. Tiga jenis usaha berbasis rumah yang berhasil teridentifikasi mempunyai strategi spasial yang berbeda satu dengan yang lain. Strategi spasial yang diterapkan mempunyai keterkaitan dengan karakterisitk penggunaan ruang yang dimiliki masingmasing jenis usaha.

Jenis usaha produksi dengan karakterisitk penggunaan ruang campuran mempunyai strategi spasial shifting Keterkaitan teridentifikasi dimana karakterisik penggunaan ruang campuran yang dicirikan dengan adany a 
ruang multiuse diikuti dengan strategi spasial shifting yang dicirikan dengan penggunaan ruang yang dibedakan waktu penggunannya. Maka dapat disimpulkan bahwa karakteristik penggunaan ruang campuran diikuti dengan strategi spasial sfihting dalam upaya pengembangan $\mathrm{HBE}$, dengan titik berat pada penggunaan ruang multiuse yang dibedakan dalam waktu penggunaan.

Usaha jasa dengan karakteristik penggunaan ruang berimbang dicirikan dengan mulai adanya batasan antar ruang hunian dan ruang usaha, namun batasan yang ada belum mampu memisahkan kegiatan usaha dan kegiatan hunian secara utuh. Hal tersebut sejalan dengan strategi spasial yang digunakan yaitu sharing dimana berupaya menciptakan ruang tambahan dengan modifikasi ruang yang tersedia. Modifikasi ruang yang ada untuk menciptakan ruang usaha akan tetap mempunyai keterkaitan dengan ruang hunian, walaupun sudah terdapat batasan antara ruang usaha dan ruang hunian. Maka disimpulkan karakteristik penggunaan ruang berimbang diikuti dengan strategi spasial sharing, dengan titik beratnya pada mulai terdapat batasan antar ruang usaha dan hunian namun masih terdapat keterkaitan antar ruang usaha dan hunian bahkan berpotensi terjadi overlapping space dari ruang usaha.

Jenis usaha penjualan dengan karakteristik penggunaan ruang terpisah dicirikan dengan adanya batasan yang kuat antara ruang usaha dan ruang hunian. Batasan yang ada juga berdampak kuatnya pemisahan antara kegiatan usaha dan kegiatan hunian. Karakterisitk penggunaan ruang tersebut diikuti dengan strategi spasial extending. Strategi spasial extending dicirikan dengan penambahan ruang baru khusus untuk ruang usaha. Penambahan ruang baru dilakukan dalam teritori hunian secara khusus sehingga kegiatan hunian terhindar dari kemungkinan overlapping space dari kegiatan usaha. Maka dapat disimpulkan bahwa karakteristik penggunaan ruang terpisah diikuti dengan strategi spasial extending, yang menitikberatkan pada penambahan ruang khusus usaha dan batasan yang kuat antara kegiatan usaha dan kegiatan hunian.
Ketiga jenis usaha dengan masing-masing karakterisik penggunaan ruang dan strategi spasialnya membuktikan bahwa adanya keterkaitan antara karakteristik penggunaan ruang dengan strategi spasial yang kemudian dapat dijadikan acuan dasar dalam upaya pengembangan Home-Based Enterprise. Strategi spasial yang digunakan pelaku HBE cenderung untuk mengoptimalkan ruang hunian yang menjadi hak milik dan aset. Pelaku HBE berusaha untuk tidak memanfaatkan ruang publik dalam hal ini dapat berupa jalan, pekarangan, atau ruang publik lain dimana terdapat impilaksi terhadap kehidupan sosial. Strategi adaptasi ruang dengan beragam penyesuaiannya menjadi pilihan dalam pengembangan HBE di permukiman Kota Surakarta.

\section{UCAPAN TERIMAKASIH}

Pada penelitian ini kami mengucapkan terima kasih kepada Narasumber yang telah memberikan informasi yang bermanfaat dalam penelitian ini. Ucapan terimakasih jug a kepada teman-teman PWK UNS 2017 yang telah memberi dukungan sehingga dapat terselesaikannya penelitian ini.

\section{REFERENSI}

Adianto, J., \& Gabe, R. T., (2019), The spatial strategies and its mechanism of homebased enterprise in Kampong Cikini, Jakarta. A/Z ITU Journal of the Faculty of Architecture, 16(2), 55-68.

Adianto, J., \& Gabe, R. T., (2020). HomeBased Enterprise and It's Impediment Factors to Self-Help House Improvement in Kampong Cikini, Jakarta. International Journal of Built Environment and Scientific Research Volume 04 Number 01, hal.49 - 60

Arifin, L.S. \& Fifinella, (2019). Kajian Tempat Penjemuran Ikan di Kampung Nelayan Kenjeran. Semarang: Jurnal eDimensi Arsitektur Vol.VII No.1, hal.593-600

Arisngatiasih, A. \& Muktali, M., (2015). Pola Penggunaan ruang pada Usaha Berbasis Rumah (UBR) di Klaster Batik Jenggot Kota Pekalongan. Jurnal Wilayah dan Lingkungan, 3(3), 175188. doi: 10.14710/jwl.3.3.175-188. 
Atika, F.A. dkk., (2019), Proporsi Fungsi Hunian dan Fungsi Usaha pada Home Based Enterprise Desa Klangonan: ITAAT Surabaya, dalam Semnas Sains dan Teknologi Terapan VII

Brown, D., McGranahan, G., \& Dodman, D. (2014), Urban informality and building a more inclusive, resilient and green economy. International Institute for Environment and Development.

Cross, J., \& Karides, M. (2007). Capitalism, Modernity, and The "Appropriate" Use of Space. In Street Entrepreneurs People, Place, and Politics in Local and Global Perspective (hal. 19-35). New York.

David, A.O., dkk. (2013). Impacts of Home Based Enterprises on the quality of Life of Operators in Ibadan North Local Government. Nigeria: International Journal of Humanities and Social Science Invention Vol.2 Issue.7, pp. 01 07

Fransen, J. \& Gaol, P.H.I. (2016). Absorptive Capacity and Local Networking of Home-Based Enterprises in Kampong Cyber, Yogyakarta.

Hadebe, T. (2010). Township Home-Based Enterprises: The case of Pimville. Johannesburg: Thesis. University of the Witwatersrand

Kellet, P \& Tipple G. (2002). Home-Based Enterprise and Housing Policy: Evidence from India and Indonesia. Newcastle: University of Newcastle upon Tyne presented at ENHR Conference in Vienna 2002

Lawanson, T. (2012). Poverty, Home Based Enterprises and Urban Livelihoods in the Lagos Metropolis. Jurnal of Sustainable Development in Africa Vol.14 No.4, presented at $48^{\text {th }}$ ISOCARP Congress 2012

Lukitaningrum, D. L., Tyas, W. P., \& Muktiali, M. (2017). Analisis Keberlanjutan Home Based Enterprise Pengolahan Singkong di Kota Salatiga . Jurnal Pengembangan Kota. Vol 5 (2): 166-180. DOI: 10.14710/jpk.5.2.166180

Olanrewaju, D. (2012). The Home as Workplace: Investigating Home Based Enterprises in Low Income Settlements of the Lagos Metropolis.Nigeria: ISOCARP Congress

Rahayu, Buchori I, and Widjajanti R, (2020). Upaya Penataan Lingkungan Sosial dan Ekonomi Pedagang Kaki Lima di Kota Surakarta Berdasarkan Tipologi Lokasi Stabilisasi Surakarta, Jurnal Wilayah dan Lingkungan, vol. 8, no. 1, pp. 5166,

Rahayu, M.J. (2020). Stabilisasi Pedagang Kaki Lima di Ruang Publik Kota Surakarta : Strategi Informalitas Perkotaan yang Berkeadilan. Surakarta : Yayasan Kita Menulis

Santos, M. (1975). The Shared Space: The Two Circuits of the Urban Economy in Underdevelopment Countries. Methuen London and New York.

Safeyah, M. \& Elviana, E. (2016). A Study on Home Based Enterprises in Kampoeng Pandean as supporting Sustainable Architecture. Surabaya: EDP Sciences Matec Web Of Conferences 58

Suparwoko \& Raharjo, W. (2019). HomeBased Enterprises in the International Kampong of Sosrowijayan: Housing Typology and Hybrid Cultural Approach to Tourism Development. Yogyakarta: Atlantis Press, Advances In Engineering Research vol.192

Susanti, I. dkk (2018), Tatanan Teritorial dalam Proses Transformasi Hunian. Jakarta:. Jurnal Arsitektur Zonasi UPI Vol.1 No.1

Tyas, W.P. (2009). Home Based-Enterprises as an Income Generator for Low Income People: $\quad$ Toward a Sustainable Financing and Economic Housing. Semarang: Universitas Diponegoro 